YEARBOOK

of ANTITRUST

and REGULATORY

STUDIES

www.yars.wz.uw.edu.pl
Peer-reviewed scientific periodical, focusing on legal and economics issues of antitrust and regulation. Creative Commons Attribution-No Derivative Works 3.0 Poland License

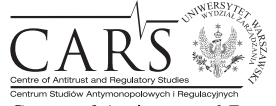

Centre of Antitrust and Regulatory Studies,

University of Warsaw, Faculty of Management www.wZ.uw.edu.pl

\title{
The Permissibility of Exclusive Transactions: Few Remarks in the Context of Exercising Media Rights
}

\author{
by
}

Jarosław Sroczyński*

\section{CONTENTS}

I. Introduction

II. Background - the case of Canal+/PZPN

1. Exclusivity agreements

2. The challenged practice

3. Key conclusions of the President of the Office of Competition and Consumer Protection

III. Assessment of exclusive media rights transactions

1. A sports event as a subject of rights

2. The issue of intellectual property

3. Analysis of the economic impact on the market

4. Acceptable exclusivity period

5. Other market restrictions

IV. Summary

\section{Abstract}

This article discusses issues associated with exclusive rights to broadcast television coverage of sports events, in light of a decision of the President of the Office of Competition and Consumer Protection (hereafter, the UOKiK President) relating to a long-term licence agreement between the Polish Football Association (hereafter, PZPN) and Canal+. It describes the special features of a sports event as the subject of licensing rights and discusses the impact of intellectual property issues on assessing whether agreements comply with the law on competition and

* Dr. Jarosław Sroczyński, a lawyer and economist, and a partner in the law firm Markiewicz \& Sroczyński. From 1990 to 1994 he was the Director of the Cracow Branch of the Antimonopoly Office. 
consumer protection. Emphasis is put on the special role of analysing each case of exclusivity economically, particularly with regard to its long-term market effects and the significance of additional restrictions accompanying exclusivity. Attention is also drawn to the precedential nature of the position of the UOKiK President that media licences can, in justified cases, cover periods of several years.

\section{Résumé}

Larticle traite de questions liées à l'exclusivité en matière de retransmission télévisée d'évènements sportifs, à la lumière de la décision du Président de l'OCCP (Office polonais de la protection de la concurrence et des consommateurs) portant sur le contrat d'exploitation pluriannuel conclu entre la Fédération polonaise de football et Canal+. Lauteur y présente les caractéristiques particulières des manifestations sportives faisant l'objet de droits d'exploitation. Larticle aborde également la question de l'impact de la propriété intellectuelle sur l'appréciation de la conformité des contrats conclus avec le droit de la protection de la concurrence et des consommateurs. Lauteur souligne par ailleurs le rôle particulier de l'analyse économique de chaque cas d'exclusivité, notamment de l'impact exercé sur le marché sur une période plus longue et de la portée des restrictions supplémentaires accompagnant l'exclusivité. Enfin, l'article évoque la position d'un précédent du Président de l'OCCP, en vertu de laquelle les droits d'exploitation peuvent, dans des cas justifiés, être cédés pour plusieurs années.

Classification and key words: exclusivity agreements; exclusivity; intellectual property; audiovisual work; sports event; media rights; UOKiK; the Polish Football Association; PZPN; Canal+.

\section{Introduction}

Exclusive transactions concluded between companies with substantial market shares are one of the more complex issues of competition law, particularly where exclusivity is granted by an entity with a monopolistic position to an entity which subsequently exploits the rights it acquires in specific areas of intellectual property. Such a situation occurs when exclusive rights to broadcast sports events in the media are licensed to television broadcasters by their organisers, which are usually sports associations. The basic problem which the anti-monopoly regulator should settle in such a case is the acceptability of exclusivity itself as a form of commercial cooperation between the parties to the transaction. Another issue is the acceptable duration of exclusivity, provided of course that the anti-monopoly authority has not decided to prohibit it. Thirdly, it must analyse possible monopolistic consequences of such aspects of 
transactions as the scope of the exclusivity granted, the possibility of it being extended, the impact on the market situation of third parties, particularly competitors, etc.

This article discusses the above issues in the context of a specific case which was dealt with by the Polish anti-monopoly authorities in connection with an exclusive licence to exercise media rights to league matches granted to Canal+ by the Polish Football Association (hereafter, the 'PZPN').

\section{Background - the case of Canal+/PZPN}

\section{Exclusivity agreements}

The issues outlined in the introduction to this article relate to a licensing agreement concluded in 2000 between the television company Canal+ and the PZPN, by virtue of which Canal+ obtained the exclusive right to broadcast coverage of football league matches, i.e. Polish Cup and Polish League Cup matches. The agreement was concluded for the league seasons from 2001/2002 to $2004 / 2005$, and provided for the possibility of an extending, as well as granting Canal+ a priority right for the 2005/2006 to 2008/2009 seasons.

The way in which that agreement was performed was challenged by the UOKiK President who, having carried out explanatory and anti-monopoly proceedings, issued a decision finding that the actions of the PZPN and Canal+ were an agreement restricting access to the market or eliminating companies not covered by the agreement from the market. ${ }^{1}$ Fines ${ }^{2}$ were imposed on the parties for breaching the statutory prohibition on concluding such agreements ${ }^{3}$. The parties filed appeals against the decision of the UOKiK President to the Court for Competition and Consumer Protection, which were dismissed by that court ${ }^{4}$, as were the appeal ${ }^{5}$ and cassation appeal ${ }^{6}$ subsequently filed by Canal+.

${ }^{1}$ Decision of the UOKiK President of 29 May 2006, DOK-49/06.

2 Article 5(1)(6) of the Act on Competition and Consumer Protection of 15 December 2000 (consolidated text: Journal of Laws of 2005 No. 244, item 2080, as amended), which was replaced by the current Act on Competition and Consumer Protection of 16 February 2007 (Journal of Laws 2007 No. 50, item 331, as amended). The substantive provisions of the two laws relating to the case in question are identical.

3 A = fine of approximately PLN 7.4 million was imposed on Canal+ and ultimately, a fine of approximately PLN 225,000 was imposed on the PZPN.

4 Judgement of the Court for Competition and Consumer Protection of 14 February 2007, XVII Ama 98/06, UOKiK Official Journal 2007 No. 2, item 22.

5 Judgment of the Court of Appeals of 4 December 2007, VI ACa 848/07.

6 Judgment of the Supreme Court of 7 January 2009, III SK 16/08. 


\section{The challenged practice}

The practice challenged by the UOKiK President essentially consisted of Canal+ guaranteeing itself a priority right to obtain an exclusive licence to exercise media rights after a period of four years from the conclusion of the agreement. The subject of the licence were the rights to make available to any audience all or a part of any league football match, as well as exclusive access to information in all fields of exploitation (e.g. highlights and film clips).

With regard to the seasons from 2005/2006 to 2008/2009, the priority right was to be exercised as follows: if the PZPN received an offer during the term of the agreement relating to purchasing or obtaining a licence for the rights subject to the agreement, it would be obliged to notify Canal+ of that offer in writing, specifying its conditions. Canal+ could inform the PZPN that it was exercising its priority right, and the PZPN would then be obliged to conclude a new agreement with Canal+ on granting an exclusive licence for the period covered by that right, on terms similar to those specified in the most favourable offer submitted by another entity.

In 2004, the PZPN invited television and internet broadcasters to participate in a tender procedure for audiovisual rights to league matches for the seasons from 2005/2006 to 2007/2008. The licences offered by the PZPN were divided into 'blocks of rights', the most attractive of which for television broadcasters was the 'Main Broadcaster's Block'. The participants in the tender procedure were informed that Canal+ had the right to submit an offer for that block, i.e. a unilateral option to acquire the rights to it on the same terms as the most favourable terms for PZPN offered by any of the other bidders. The UOKiK President of found that this understanding had a negative impact on the relevant market by a deliberate restriction of competition, which was confirmed in the course of the proceedings by the television stations Polsat and TVP, among others.

\section{Key conclusions of the President of the Office of Competition and Consumer Protection}

The position of the UOKiK President on the issue of exclusivity set out in Decision No. DOK-49/06 is of key significance ${ }^{7}$. It is worth quoting it in full: 'Both Polish and Community competition law has approached and approaches the conclusion of exclusivity agreements very carefully. If the commercial context indicates that concluding such agreements is commercially rational

\footnotetext{
${ }^{7}$ See the justification for the decision, p. 28.
} 
and brings appropriate benefits to the economy and consumers, exclusivity can be used. However, the period for which it is granted should not be longer than is absolutely necessary for the correct performance of the agreement, in view of the harmful effect of exclusivity on the competitiveness of the market. In these proceedings, the anti-monopoly authority does not challenge the granting of an exclusive licence, and finds that exclusivity as such is essentially an element of the functioning of the markets for trading in media rights. Nor does the President of the Office challenge the period for which the licence for exercising the rights in question was granted, but finds that it was long enough to, on the one hand, provide the licensor and licensee with appropriate commercial benefits on account of granting/purchasing the licence and, on the other, short enough not to have a lasting adverse effect on the competitiveness of the market in question. However, the conclusion in 2000 of an agreement for an exclusive licence for a period of more than four years could result in that period being challenged as being too long and in violation of the rules of competition law'.

In the context of the above position of the UOKiK President, we should consider the definition of the relevant market applied in the case in question, i.e. the market for trading in rights to broadcast Polish league football matches. The PZPN holds a 100 per cent share of that market, which means it is a monopoly holder with regard to licensing media rights. In view of the above, the case was not subject to the exemption relating to agreements of minor importance (the 'de minimis' rule) or the regulation on group exemptions with regard to vertical agreements. When defining the relevant market, the UOKiK President made use of specialist knowledge on consumer choices. For that purpose, an analysis was carried out by a research institute, which showed that on the demand side a narrow definition of the market is appropriate, because television broadcasts of Polish league matches are not substitutable with regard to broadcasts of other football matches or other sports events, even those considered 'premium' events ${ }^{8}$.

8 For example, the football world championships, Formula 1 races, a ski-jumping final, etc. An analysis of the definitions of media markets applied in EU countries is set out in an extensive report prepared for the European Commission by the law firm Bird \& Bird: Market Definition in the Media Sector - A Comparative Analysis, DG Competition, December 2002. 


\section{Assessment of exclusive media rights transactions}

\section{A sports event as a subject of rights}

The legal nature of rights to broadcast media coverage of sports events has been the subject of several studies in Polish legal literature ${ }^{9}$. To briefly summarise the arguments they contain relating to the scope of protection in question, we must consider three basic areas: direct broadcasts of sports events, recordings of those events, and the accompanying information layer including commentaries, sports interviews and reviews of reports on ongoing sports events. The basic means of protection is the protection under the Law on Copyright and Neighbouring Rights afforded to 'works' in the meaning of that act. Whether 'live' or in the form of a recorded videogram, a television broadcast is eligible for the protection due to audiovisual works ${ }^{10}$. Usually, information elements of sports events, e.g., commentaries, will also be works under copyright law (please note that many of them will in any case be a constituent part of an audiovisual work, which a sports broadcast is). Despite the doubts that arise when analysing the possibility of providing legal protection for a sports event 'as such'11, i.e. protection that takes into account the interests of 'players/actors' and the organiser of the event, there is therefore no question that a wide range of exclusive rights of television organisations exist relating to virtually any form of broadcast of a sports event.

${ }^{9}$ Particularly noteworthy is the monograph by K. Wojciechowski, Widowisko sportowe $w$ telewizji (Widowisko sportowe i audiowizualna relacja $z$ niego jako dobra chronione $w$ świetle polskiego prawa prywatnego), Warszawa 2005. See also J. Barta, R. Markiewicz, 'Widowisko sportowe a prawo autorskie' (1996) 67 Zeszyty Naukowe UJ, Prace z Wynalazczości i Ochrony Własności Intelektualnej; R. Piechota, 'Prawa do transmisji widowisk sportowych - zarys problemu' (2006) 5-6(497-498) Sport Wyczynowy 55-61; J. Sobczak, 'Prawa mediów w zakresie dostępu do informacji sportowych i do przekazania tych informacji' [in:] M. Kępiński (ed.), Sport i media - problemy prawne, published as: (1997) 6 Sport i Prawo; M. Czajkowska-Dąbrowska, 'Utwory audiowizualne, utwory wideograficzne, wideogramy: między prawem autorskim a prawami sąsiednimi' (1993) 61 Zeszyty Naukowe UJ, Prace z Wynalazczości i Ochrony Wtasności Intelektualnej; J. Szczotka, 'Rejestracja audiowizualna w świetle polskiego prawa autorskiego' (1988) 47 Zeszyty Naukowe UJ, Prace z Wynalazczości i Ochrony Wtasności Intelektualnej; A. Wojciechowska, 'Twórcy dzieła audiowizualnego w świetle ustawy o prawie autorskim i prawach pokrewnych z 4 lutego 1994 r.' (1996) 67 Zeszyty Naukowe UJ, Prace z Wynalazczości i Ochrony Wtasności Intelektualnej.

10 Article 1(2)(9) of the Law on Copyright and Neighbouring Rights of 4 February 1994 (consolidated text: Journal of Laws 2006, No. 90, item 631).

11 With regard to this issue, see the de lege ferenda proposal to introduce a 'stadium right' into Polish copyright law as a new neighbouring right, J. Barta, R. Markiewicz, 'Widowisko sportowe...', p. 30. See also M. Burnett, 'Thirty-four years on: high time for filling the gaps in broadcasters' protection' (1995) 6(2) Ent. L. R. 39-41. 
There are also interesting deliberations on entity-related issues associated with the acquisition of rights to broadcast league matches. It appears that the originally entitled entity is the PZPN as the main organiser of the league matches, although it can be argued that exclusive rights first arise to the benefit of football clubs as the organisers of individual matches. Further, with regard to any match, joint rights can be attributed to the two teams playing a football match ${ }^{12}$. In any case, the acquisition of exclusive rights to create a broadcast of Polish league matches by a television broadcaster should be classified as an acquisition by transfer, as they are acquired from the originally entitled party PZPN, which is entitled, as the organiser of the matches, to a kind of 'commercial exclusivity' with regard to the exploitation of a sports event $^{13}$. With regard to created audiovisual works, i.e. recordings of league matches, the original creator's right is held by the television company. These seemingly theoretical deliberations may have practical value, as, in the case being analysed, the PZPN transferred to Canal+ a different right than the one subsequently exploited by Canal+. We should therefore consider the possibility of concluding that PZPN's actions involving the one-off disposal (assignment) of its rights to another entity are permissible. It appears that such reasoning would be justified from the standpoint of the needs of trading, according to which a sports association should be flexible in selecting a single contract partner instead of engaging energy and funds in negotiations with multiple television broadcasters. In this way, the focus of the legal assessment would shift from the issue of a prohibited agreement restricting competition to the issue of the consequences of a long-term unilateral restriction. An assessment of a possible refusal by the originally entitled party to grant other television broadcasters a licence to broadcast audiovisual works, i.e. broadcasts of league matches, could also be relevant ${ }^{14}$. Such a refusal would then be subject to

12 Joint rights are regulated in Article 14 par. 2 item 1 the Statute of the PZPN, which provides that 'PZPN and clubs participating in the two highest match classes are the co-owners $[\ldots]$ of the proprietary and non-proprietary rights to the matches, in particular television, advertising and marketing rights exercised with regard to the above-mentioned events and matches via available audiovisual, radio and audio means and the Internet and any other technical means existing now or in the future'. However, one may note that this provision can be classified as a formalisation of contractual relationships.

13 See J. Barta, R. Markiewicz, 'Widowisko sportowe...', p. 27; A. Pedriali, K. N. Peifer, 'Der Schutz des Veranstalters von Sportereignissen nach italienischem Recht' (1994) 8-9 ZUM 462; S. Graf Von Wallwitz, 'Sports between politics and competition law - the central marketing of television rights to sports events in light of German and European competition law' (1998) 9(6) Ent. L. R. 216-221; S. Schmitz, P. Brautigam, 'German football broadcasting at a turning point: the Supreme Court's decision on the central marketing of television right' (1998) 9(3) Ent. L. R. 122-125.

14 According to the assessment of the German Supreme Court in a case relating to central trading in rights to broadcasts of domestic league matches by the GFA (the equivalent of the 
assessment in light of Article 9 of the Competition Act, i.e. relating to an abuse of a dominant position involving exclusion from the market or being, in the case of an inflated licence fee being charged, of an exploitive nature. It is worth referring here to the well-known case of Microsoft, in which the European Commission issued a decision on an obligation to grant competitors licences for exclusive rights relating to intellectual property ${ }^{15}$. The matter is obviously not clear-cut, because it would require that the practice whereby a live sports event is broadcast exclusively by a single television broadcaster be broken. On the other hand, an encoded and paid television channel is less accessible than free-to-air channels, and the PZPN's offer includes different types of broadcast packages. This could be an argument in support of an obligation to 'share' licences or 'split' them up among other broadcasters.

2. The issue of intellectual property

If television broadcasts of sports events constitute an intellectual asset, does that fact justify agreements providing for long-term exclusivity granted by the entitled party to a single broadcaster selected by it being afforded special treatment? The antimonopoly law does not affect rights under the laws relating to the protection of intellectual and industrial property, particularly those on the protection of inventions, utility and industrial designs, integrated circuit topography, trademarks, geographical markings and copyrights and neighbouring rights (Article 2(1) of the Competition Act). This means that, in principle, competition law does not challenge a monopoly stemming from intellectual property rights resulting from individual creative activities. This principle applies in all major legal systems, both in Europe and the rest of the world. The rule of the non-interference of antimonopoly law in the substance of a monopoly, e.g. a patent or copyright law monopoly, is the basic 'demarcation line' between those areas of law, and its ratio is expressed in the need to strike a balance between the public/legal need to regulate the sphere of commercial relations to protect the socially positive phenomenon of competition and the need to allow

Polish PZPN), the GFA cannot be deemed to have committed a monopolistic violation if it was the entity duly authorised to conclude such 'central' transactions (judgement of 11 December 1997, WuW 160, Fernsehübertragungsrechte I). This is related to the definition of two levels of the relevant market in cases involving sports licences, i.e. the market for purchasing rights to programme content (materials) and the market for disseminating them to viewers. With regard to this issue see K. Wojciechowski, Widowisko sportowe..., p. 302; R. Subiotto, T. Graf, 'Analysis of the Principles Applicable to the Review of Exclusive Broadcasting Licenses Under EC Competition law' (2003) 26(4) World Competition 591.

15 Judgement of CFI in the case T-201/04 Microsoft Corp. v. the Commission [2007] ECR II-03601. See also decision of the UOKiK President of 12 February 2010, DOK-1/2010, in the case of Cyfrowy Polsat S.A., in which it was found that that company abused its dominant position on the domestic market for the sale of rights to publicly reproduce coverage of EURO 2008, which involved applying practices involving tie-in transactions. 
creators freedom in shaping those relationships, which is inevitably related both to the commercialisation of creative products and the more general issue of the protection of unrestricted intellectual progress (technical and creative), which of course remains also in the public interest ${ }^{16}$.

\section{Analysis of the economic impact on the market}

Let us again consider the assessment set out in decision of the UOKiK President No. DOK-49/06, according to which exclusive agreements are an element of the functioning of the markets for trading in media rights, and that concluding such agreements can be assessed as commercially rational in view of the benefits that can stem from them for both the economy and consumers. It should be stressed that functional (primarily economic) criteria are used in that assessment, as the key issue is the commercial rationality of exclusive agreements, which constitutes a reference to the 'rule of reason' set out in Article 8(1) of the Competition Act. That principle can also apply to exclusive contracts concluded between enterprises having a significant market share, or even a monopolistic position. It is necessary for the condition of commercial benefits to be satisfied, i.e. an improvement in the production or distribution of goods or of technical or commercial progress. An appropriate portion of those benefits must be transferred to buyers or users, and any restrictions related to an exclusivity clause (above all restrictions that block access to the market, i.e. foreclosure) must be essential to achieve the intended business objectives and not lead to the elimination of competition on the relevant market to a significant degree ${ }^{17}$. On the other hand, the 'rule of reason' provided in

${ }^{16}$ K. Kohutek, M. Sieradzka, Ustawa o ochronie konkurencji i konsumentów - Komentarz, Warszawa 2008, p. 75-79; G. Materna, 'Stosowanie prawa ochrony konkurencji wobec organizacji zbiorowego zarządzania - granice ingerencji organu antymonopolowego' [in:] K. Lewandowski (ed.), Prawo autorskie a prawo konkurencji, Poznań 2009, p. 47-50; I. Wiszniewska, Granice kartelowo-prawne ważności licencji patentowych, Wrocław-Warszawa-Kraków 1991, p. 116-133. With regard to foreign literature see, for example, C. Crampes, D. Encaqua, A. Hollander, 'Competition and Intellectual Property in the European Union' [in:] R. Clarke, E. Morgan (eds), New Developments in UK and EU Competition Policy, Bodmin 2006; J. Turner, Intellectual Property Law and EU Competition Law, Oxford 2010; H. Hovenkamp, M. D. Janis, M. A. Lemley, IP and Antitrust, An Analysis of Antitrust Principles Applied to Intellectual Property Law, New York 2004; H. Hovenkamp, 'The Intellectual Property - Antitrust Interface' (2008) 8-46 the University of Iowa Legal Studies Research Paper. With regard to EU case law see, in particular, the rulings in the case of Magill, judgement of 6 April 1995, C-241\& 242/91 [1995] ECR I-00743 and Coditel II, judgement of 18 March 1980, C-62/79 [1980] ECR 00881.

17 T. Skoczny, A. Jurkowska, D. Miąsik (eds.), Ustawa o ochronie konkurencji i konsumentów. Komentarz, Warszawa 2009, p. 449; C. Banasiński, E. Piontek (eds.), Ustawa o ochronie konkurencji i konsumentów. Komentarz, Warszawa 2009, p. 227. 
Article 2(2) of the Competition Act with regard to agreements on licensing exclusive rights sets a different standard, providing that the antimonopoly law only applies to those agreements if they result in unjustified restriction of the parties' freedom of business activity or a significant restriction of competition on the market. The difference between an anti-monopoly assessment of licence agreements and an assessment of other agreements of a vertical nature subject to the provisions of Article 6 of the Competition Act, which provides for a prohibition on concluding understandings which violate competition, therefore includes the fact that while a monopolistic objective of those understandings is alone sufficient for them to be prohibited (i.e. there need not necessarily be a monopolistic consequence), agreements on licensing intellectual and industrial property rights can only be prohibited after their monopolistic market consequences have been demonstrated. The strictness of the prohibition envisaged in the Competition Act is therefore reduced in the case of licence agreements, which is related to their special nature, involving trading in exclusive rights ${ }^{18}$. Similarly, if we hypothetically classify the actions of the television broadcaster as an abuse of a dominant position involving refusing to grant a licence for exclusive rights to competing television broadcasters, such action could be justified on the basis of the 'reasonableness clause' under Article 2(2), while the clause under Article 8(1) would no longer be applicable to it.

One should note that the criteria set out in Article 8(1) and Article 2(2) of the Competition Act cannot be treated only generally, despite the fact that their wording may appear imprecise. The functional/economic approach to competition law, which has been particularly apparent since Poland's accession to the European Union, means that in the circumstances of a specific case it will be essential to present arguments showing that a concluded understanding is beneficial. The arguments must be provided by the interested parties themselves, i.e. the parties which concluded the agreement ${ }^{19}$, and will usually be

18 The specific nature of licence agreements and resulting modifications of the antimonopoly assessment applied in the case of 'ordinary' agreements were the subject of analyses carried out by the European Court of Justice in the judgment of 25 February 1986 193/83 Windsurfing International Inc. v. the Commission [1986] ECR 611. With regard to this issue, see also the the judgment of 8 June 1971, 78/70 Deutsche Grammophon Gesellschaft mbH v. Metro-SB-Großmärkte GmbH \& Co. KG [1971] ECR 00487. See also R. Poździk, Dystrybucja produktów na zasadzie wyłaczności w Polsce i Unii Europejskiej, Lublin 2006, p. 162.

19 Pursuant to Article 8(2) of the Competition Act, the burden of proof with regard to a 'reasonableness clause' rests on the company which derives favourable legal consequences from it. Because the scopes of both 'reasonableness clauses', i.e. that under Article 2(2) and that under Article 8(1) are to a large extent identical, and the objective of applying those clauses is also the same, it should be noted that although there is no equivalent of Article 8(2) with regard to assessing licence agreements, in this case too the parties to the agreement should be able 
economic market analyses demonstrating the market power of the key players on the relevant market, research into or extrapolations of market development trends, analyses of the impact of the transactions concluded on the situation of consumers, analyses of barriers to entry into the market, analyses of 'economies of scale', cumulative effects, etc. A helpful methodology could be the 'significant impediment of effective competition' test (SIEC), which the anti-monopoly authority uses when assessing the effects of market concentrations ${ }^{20}$.

\section{Acceptable exclusivity period}

An analysis of economic effects will be essential when establishing the acceptable duration of restrictions resulting from exclusivity granted under a licence agreement. As pointed out above, the UOKiK President found that, in the case of media rights licences, a period of more than four years should be considered as having a significant and lasting negative impact on competition on the relevant market, while a period not exceeding four years was approved by the UOKiK President. The question therefore arises as to whether there are circumstances which justify concluding agreements on media exclusivity for a longer period. Let us remember that the agreement between PZPN and Canal+ envisaged exclusive relations between the parties that could continue

to demonstrate that the positive effects of the agreement outweigh the negative consequences for competition. See D. Miąsik, Reguła rozsądku w prawie antymonopolowym, Zakamycze 2004, p. 383; I. Wiszniewska, Reguly konkurencji a transakcje wytaczne, Warszawa 1995, p. 80-83.

20 See Article 18 of the Competition Act, pursuant to which the UOKiK President consents to a concentration which will not result in competition on the market being significantly restricted, in particular by the creation or reinforcement of a dominant position on the market. See T. Skoczny, 'Polskie prawo kontroli koncentracji - ewolucja, model, wybrane problemy' (2010) 5 Europejski Przeglą Sądowy 15; J. Sroczyński, 'Kiedy koncentracje mogą zagrozić konkurencji’ [in:] M. Krasnodębska-Tomkiel (ed.), Zmiany w polityce konkurencji na przestrzeni ostatnich dwóch dekad, Warszawa 2010, p. 213. Statements have been made on several occasions in legal literature on the phenomenon of the economisation of competition law after 2000; see, for example, A. Jurkowska, T. Skoczny, 'Ekonomizacja wspólnotowej polityki konkurencji - założenia a realizacja' [in:] A. Stępniak, S. Umiński, A. Zabłocka (eds.), Wybrane problemy integracji europejskiej, Sopot 2009, pp. 183-184; A. Fornalczyk, Biznes a ochrona konkurencji, Kraków 2007; K. Kohutek, 'Modernizacja instytucji zakazu nadużycia pozycji dominującej w prawie konkurencji: nowe koncepcje oraz metody stosowania prawa' (2010) 6 Przegląd Prawa Publicznego 84. See also the collection of reports [in:] C. Banasiński, E. Stawicki (eds.), Konkurencja w gospodarce wspótczesnej, Warszawa 2007, and in it in particular: A. Fornalczyk, 'Strategie konkurencyjne przedsiębiorstw i ochrona rynku przed skutkami dominacji rynkowej’, p. 80; E. Jantoń-Drozdowska, 'Ekonomiczne przesłanki antymonopolowej oceny koncentracj', p. 269; N. Szadkowski, 'Drapieżnictwo cenowe w teorii ekonomii i w praktyce orzeczniczej polskiego organu antymonopolowego', p. 287; U. Dubejko, 'Wykorzystanie analizy ekonomicznej przy określaniu siły rynkowej przedsiębiorców w sprawach z zakresu nadużywania pozycji dominującej i kontroli łączeń’, p. 326. 
in various forms until 2009, i.e. for nine years. There was a case where the European Commission granted a permit, albeit on special conditions, for even a fifteen-year period for exclusive exploitation of rights to disseminate film works ${ }^{21}$. On the other hand, with regard to some long-term agreements relating to the dissemination of broadcasts of sports events, the Commission challenged the excessively long exclusivity periods, for example an eleven ${ }^{22}$ or seven-year period $^{23}$. Shorter periods lasting from three to five years therefore predominate ${ }^{24}$. Establishing a consistent rule is thought to be virtually impossible, because the circumstances of each case will always be significantly different ${ }^{25}$. There will also be differences in the nature of the transaction being concluded, i.e. whether it will involve only contractual relations (a licence agreement) or also relate to structural changes in the market (concentrations of undertakings ${ }^{26}$ ). When analysing exclusivity clauses on the market for trading in sports broadcast rights with regard to concentrations, we can also consult the general principles provided in Commission Notice on restrictions directly related and necessary to concentrations ${ }^{27}$. The permissibility of such restrictions results from the fact that, for a purchaser to obtain the full value of the assets being transferred, the seller

21 See decision 89/536/EEC of 15 September 1989, ARD/MGM/UA, OJ [1989] L 284.

22 The case of Sogecable/Telefonica (Press Release IP/00/372).

23 The case of $K N V B /$ Sport7, OJ [1996] C 228/4.

${ }^{24}$ See the following European Commission decisions: 2003/778/EC, UEFA Champions League, OJ [2003] L 291/25; 2005/396/EC, Bundesliga, OJ [2005] L 134/46; 2001/C 169/03 FIA/ Formula 1 (approvals for a period of three years, OJ [2001] C 169/5); 2008/C 7/10, Premier League, BskyB and BBC (approval for a period of five years, OJ [2008] C 7/18).

25 As stated by, for example, R. Subiotto, T. Graf, 'Analysis of the Principles...', p. 589-599. See also, with regard to the issue of time restrictions on the freedom to licence exclusive rights to sports events, T. Toft, 'Football: Joint Selling of Media Rights' (2003) 3 EC Competition Policy Newsletter 47; H. Ungerer, 'Commercialising Sport: Understanding the TV Rights Debate', Barcelona, 2 October 2003. See also a discussion relating to exclusivity principles in the case of the Premiership, BskyB and BBC in articles by: Ch. Johnstone, Ph. Alberstat, 'Competition law and sports: the way forward' (1998) 9(4) Entertainment Law Review 174-177 and D. Geey, 'Collectivity v. exclusivity: conflict in the broadcasting arena' (2004) 15(1) Entertainment Law Review 7-11. An analysis of Spanish experiences in this respect is given by J. V. Alonso, S. M. Lage, 'The law on sports broadcast: one more 'battle' in the Spanish digital television 'war' (1998) 9(3) Entertainment Law Review 115-121, and of Italian experiences by E. Apa, 'Recent developments of the legal framework on media and sport in Italy: from the Melandri Law to the self-regulatory' (2008) 19(3) Entertainment Law Review 51-53.

26 The European Commission considered the duration of exclusivity clauses with regard to the objectives of a concentration being carried out in the case of Newscorp/Telepiu, European Commission decision of 2 April 2003 COMP/M.2876, L.110/73, in which an exclusivity period in relations with football clubs amounting to two years was found to be acceptable.

27 Published in OJ [2005] C 56, p. 24-31. See also P. Barczak, A. Michałowski, 'Klauzule o zakazie konkurencji w procesie koncentracji w europejskim i polskim prawie konkurencji' (2004) 1-2 Palestra. 
should provide it with an appropriate level of protection against competition to enable it to secure customer loyalty and assimilate and utilise the know-how being acquired. It is therefore essentially permissible when a concentration is being carried out to use clauses prohibiting the seller from competing with the purchaser with regard to the activities of the business undertaking or part thereof being sold. The effect of non-compete clauses is therefore similar to the full exclusivity that occurs in the case of a licence to use specific subjects of intellectual property rights. According to the Commission's position set out in the Notice, non-compete clauses are justified for periods of up to three years, when the transfer of a business undertaking includes the transfer of customer loyalty both in the form of goodwill and know-how, and where only goodwill is involved they are justified for periods of up to two years. Although the Commission finds that non-compete clauses cannot be deemed to be necessary when a transfer is limited to exclusive rights to industrial and commercial property, whose holders can promptly take action against any violations by the party selling those rights, we are dealing here primarily with rights which are subject to registration by the relevant state authorities (i.e. patent rights, rights stemming from the registration of trademarks, new plant varieties, etc.). By analogy, it can therefore be concluded that a two or three-year period for which a television broadcaster would have guaranteed exclusivity with regard to broadcasting sports events would be justified 'in advance', so to speak. A longer period must be directly associated with the transaction and essential for the proper achievement of its objectives. For example, the European Commission approved a period of five years relating to the automobile market ${ }^{28}$, from eight to 10 years for chemical products markets ${ }^{29}$, and seven years for the market for processing pictures used in medicine ${ }^{30}$.

\section{Other market restrictions}

It is worth considering the issue of the preferential extension of the exclusivity granted to Canal+ through the above-mentioned 'priority option'. That mechanism could have guaranteed broadcasting exclusivity for further league seasons, even until 2009, which the UOKiK President was critical about. The essence of the option and the contractual provisions relating to the manner in which Canal+ exercised it show that it is similar to the 'English clause', which is sometimes used in commercial agreements as an indirect

28 Case COMP/M1980 - Volvo/Renault VI, OJ [2000] C 220/6.

${ }^{29}$ Cf. case 76/743 - Reuter/BASF, OJ [1976] L 254/40 and case IV/M.197 - Solvay-Laporte/ Interox respectively.

${ }^{30}$ Case IV/M.1298 - Kodak/Imation. 
exclusivity mechanism. Such a clause involves granting a purchaser a right to choose (option), according to which it can decide to continue the agreement beyond the initial term provided in it, which in turn will depend on the prices that may be offered by competing purchasers for the good or service which is the subject of the agreement. The seller therefore gathers competing offers and then informs the buyer of the prices offered, whereupon the buyer decides whether it will continue the agreement or not. There are different variations of English clauses and they are sometimes similar in form to a 'most favoured nation clause'. They also vary in terms of the scope of the decision-making rights on both the seller's and the buyer's side. In specific circumstances, such clauses have an identical effect as an agreement which provides for exclusive purchasing or exclusive supply. If the parties (or a party) to the agreement have a dominant position on the relevant market, English clauses can be challenged by the anti-monopoly authority ${ }^{31}$.

In the broader context of the use of English clauses, the issue arises of the monopolistic effects of informing bidders of the content of bids submitted to organisers of sports events, as disclosing 'sensitive commercial information' to competitors could disrupt competition during tender procedures for media rights and also lead to anti-competitive coordination of market behaviour, above all through the possibility of independent pricing policy being distorted ${ }^{32}$.

\section{Summary}

The judgements issued in connection with the PZPN/Canal+ case are precedential for the market for the exploitation of media rights to sports events. They confirm that the anti-monopoly authorities accept the exclusivity of licence agreements concluded on that market, indicating that an exclusivity period of several years is acceptable. The arguments presented by the UOKiK President are also general enough that they can act as a starting point for assessing exclusive transactions on other media markets, or on other relevant markets in general, particularly if the transactions concluded contain elements of intellectual property. Examination of the circumstances of each case should take into account the economic purpose of the transaction and the actual need for a particular exclusivity period. However, various restrictions accompanying

31 The case of PKP CARGO, the decision of the UOKiK President of 17 June 2004, DOK-50/2004.

32 Article 6(1)(7) of the Competition Act. See D. E. Wojtczak, 'Zwalczanie zmów przetargowych w Polsce' (2010) 7 Państwo i Prawo 68. 
exclusivity should be approached with great care, particularly disclosure obligations leading to the dissemination of sensitive commercial information on the terms and conditions of offers submitted by third parties, which results in horizontal disruption of competition.

\section{Literature}

Alonso J.V., Lage S.M., 'The law on sports broadcast: one more 'battle' in the Spanish digital television 'war' (1998) 9 (3) Entertainment Law Review.

Apa E., 'Recent developments of the legal framework on media and sport in Italy: from the Melandri Act to the selfregulatory'(2008) 19 (3) Entertainment Law Review.

Banasiński C., Piontek E. (eds.), Ustawa o ochronie konkurencji i konsumentów. Komentarz [Act on Competition and Consumer Protection. Commentary], Warszawa 2009.

Barczak P., Michałowski A., 'Klauzule o zakazie konkurencji w procesie koncentracji w europejskim i polskim prawie konkurencji' ['Competition prohibiting clauses in concentrations in European and Polish competition law'] (2004) 1-2 Palestra.

Barta J., Markiewicz R., 'Widowisko sportowe a prawo autorskie' ['Sports event and copyright law'] (1996) 67 Zeszyty Naukowe UJ, Prace z Wynalazczości i Ochrony Wtasności Intelektualnej.

Burnett M., 'Thirty-four years on: high time for filling the gaps in broadcasters' protection' (1995) 6(2) Entertainment Law Review.

Crampes C., Encaqua D., Hollander A., 'Competition and Intellectual Property in the European Union' [in:] Clarke R., Morgan E. (eds.), New Developments in UK and EU Competition Policy, Bodmin 2006.

Czajkowska-Dąbrowska M., 'Utwory audiowizualne, utwory wideograficzne, wideogramy: między prawem autorskim a prawami sąsiednimi' ['Audiovisual works, videographical works, videograms: between copyright and neighbouring rights'] (1993) 61 Zeszyty Naukowe UJ, Prace z Wynalazczości i Ochrony Własności Intelektualnej.

Dubejko U., 'Wykorzystanie analizy ekonomicznej przy określaniu siły rynkowej przedsiębiorców w sprawach z zakresu nadużywania pozycji dominującej i kontroli łączeń' ['Application of economic analysis in determining a market power of undertaking in cases on abuse of a dominant position and concentration cases'] [in:] Banasiński C., Stawicki E. (eds.), Konkurencja w gospodarce wspótczesnej [Competition in modern economy], Warszawa 2007.

Fornalczyk A., Biznes a ochrona konkurencji [Business and competition protection], Kraków 2007.

Fornalczyk A., 'Strategie konkurencyjne przedsiębiorstw i ochrona rynku przed skutkami dominacji rynkowej' ['Competition stratgies of undertaking and protection of a market against effects of maret dominance'] [in:] Banasiński C., Stawicki E. (eds.), Konkurencja w gospodarce wspótczesnej [Competition in modern economy], Warszawa 2007.

Geey D., 'Collectivity v. exclusivity: conflict in the broadcasting arena' (2004) 15 (1) Entertainment Law Review.

Hovenkamp H., 'The Intellectual Property - Antitrust Interface' (2008) 08-46 The University of Iowa Legal Studies Research Paper. 
Hovenkamp H., Janis M. D., Lemley M. A., IP and Antitrust, an Analysis of Antitrust Principles Applied to Intellectual Property Law, New York 2004.

Jantoń-Drozdowska E., 'Ekonomiczne przesłanki antymonopolowej oceny koncentracji' ['Economic prerequisites of antitrust control of concentrations'] [in:] Banasiński C., Stawicki E. (eds.), Konkurencja w gospodarce wspótczesnej [Competition in modern economy], Warszawa 2007.

Johnstone C., Alberstat P., 'Competition law and sports: the way forward' (1998) 9 (4) Entertainment Law Review.

Jurkowska A., Skoczny T., 'Ekonomizacja wspólnotowej polityki konkurencji - założenia a realizacja' ['Economization of EC competition policy - foundations and implementation] [in:] Stępniak A., Umiński S., Zabłocka A. (eds.), Wybrane problemy integracji europejskiej [Selected problems of European integration], Sopot 2009.

Kohutek K., 'Modernizacja instytucji zakazu nadużycia pozycji dominującej w prawie konkurencji: nowe koncepcje oraz metody stosowania prawa' ['Modernisation of an institution of a prohibition of an abuse of a dominant position in competition law: New concepts and methods of law application'] (2010) 6 Przeglad Prawa Publicznego.

Kohutek K., Sieradzka M., Ustawa o ochronie konkurencji i konsumentów. Komentarz [Act on Competition and Consumer Protection. Commentary], Warszawa 2008.

Market Definition in the Media Sector - A Comparative Analysis, DG Competition, December 2002.

Materna G., 'Stosowanie prawa ochrony konkurencji wobec organizacji zbiorowego zarządzania - granice ingerencji organu antymonopolowego' ['Application of competition law to organizations of collective management of copyrights - limits of intervention of antitrust body'] [in:] Lewandowski K. (ed.), Prawo autorskie a prawo konkurencji [Copyright law and competition law], Poznań 2009.

Miąsik D., Reguła rozsądku w prawie antymonopolowym [Rule of reason in antitrust law], Kraków 2004.

Pedriali A., Peifer K. N., 'Der Schutz des Veranstalters von Sportereignissen nach italienischem Recht' (1994) 8-9 ZUM.

Piechota R., 'Prawa do transmisji widowisk sportowych - zarys problemu' ['Right to transmission of sports events - basis of the problem'] (2006) 5-6(497-498) Sport Wyczynowy.

Poździk R., Dystrybucja produktów na zasadzie wytaczności w Polsce i Unii Europejskiej [Exclusive distribution of products in Poland and the European Union], Lublin 2006.

Schmitz S., Brautigam P., 'German football broadcasting at a turning point: the Supreme Court's decision on the central marketing of television rights' (1998) 9(3) Entertainment Law Review.

Skoczny T., 'Polskie prawo kontroli koncentracji - ewolucja, model, wybrane problemy' ['Polish law of concentration control - evolution, model, selected problems'] (2010) 5 Europejski Przeglad Sadowy.

Sobczak J., 'Prawa mediów w zakresie dostępu do informacji sportowych i do przekazania tych informacji' ['Rights of media in an access to sports information and to announcing the information'] [in:] Kępiński M. (ed.), Sport i media - problemy prawne [Sport and media - legal problems] (1997) 6 Sport i Prawo.

Sroczyński J., 'Kiedy koncentracje mogą zagrozić konkurencji' ['When concentrations may be dangereous for competition'] [in:] Krasnodębska-Tomkiel M. (ed.), Zmiany w polityce 
konkurencji na przestrzeni ostatnich dwóch dekad [Changes in competition policy over last two decades], Warszawa 2010.

Subiotto R., Graf T., 'Analysis of the Principles Applicable to the Review of Exclusive Broadcasting Licenses Under EC Competition law' (2003) 26(4) World Competition.

Szadkowski N., 'Drapieżnictwo cenowe w teorii ekonomii i w praktyce orzeczniczej polskiego organu antymonopolowego' ['Predatory pricing in economic theory and in decisions of the Polish antitrust body'] [in:] Banasiński C., Stawicki E. (eds.), Konkurencja w gospodarce wspótczesnej [Competition in modern economy], Warszawa 2007.

Szczotka J., 'Rejestracja audiowizualna w świetle polskiego prawa autorskiego'['Audiovisual registration in the light of the Polish copyright law'] (1988) 47 Zeszyty Naukowe UJ, Prace z Wynalazczości i Ochrony Własności Intelektualnej.

Toft T., 'Football: Joint Selling of Media Rights' (2003) 3 EC Competition Policy Newsletter.

Turner J., Intellectual Property Law and EU Competition Law, Oxford 2010.

Ungerer H., Commercialising Sport: Understanding the TV Rights Debate, Barcelona, 2 October 2003.

Von Wallwitz Graf S., 'Sports between politics and competition law - the central marketing of television rights to sports events in light of German and European competition law' (1998) 9(6) Entertainment Law Review.

Wiszniewska I., Granice kartelowo-prawne ważności licencji patentowych [Cartel law limits of validity of patent licences], Wrocław-Warszawa-Kraków 1991.

Wiszniewska I., Reguly konkurencji a transakcje wytaczne [Competition rules and exclusive transactions], Warszawa 1995.

Wojciechowska A., 'Twórcy dzieła audiowizualnego w świetle ustawy o prawie autorskim i prawach pokrewnych z 4 lutego 1994 r.' ['Authors of audiovisual works in the light of Act of 4 february 1994 on Copyrights and Related Rights'] (1996) 67 Zeszyty Naukowe UJ, Prace z Wynalazczości i Ochrony Wtasności Intelektualnej.

Wojciechowski K., Widowisko sportowe w telewizji (Widowisko sportowe i audiowizualna relacja z niego jako dobra chronione w świetle polskiego prawa prywatnego) [Sports event on television (Sports events and its audiovisual transmission as protected goods in the light of Polish private law], Warszawa 2005.

Wojtczak D. E., 'Zwalczanie zmów przetargowych w Polsce' ['Combating tender collusions in Poland'] (2010) 7 Państwo i Prawo. 